\title{
Empowerment Academic Data as the Basis of Mapping Priority Program of Quality Assurance Organization
}

\author{
Ari Wahyudi*) \\ Faculty of Social Sciences and \\ Law Universitas Negeri Surabaya, \\ Indonesia \\ ariwahyudi@unesa.ac.id
}

\author{
Totok Suyanto \\ Faculty of Social Sciences and \\ Law Universitas Negeri Surabaya, \\ Indonesia \\ totoksuyanto@unesa.ac.id
}

\author{
M. Turhan Yani \\ Faculty of Social Sciences and Law \\ Universitas Negeri Surabaya, \\ Indonesia \\ turhanyani@unesa.ac.id \\ Mintowati \\ Faculty of Social Sciences and Law \\ Universitas Negeri Surabaya, \\ Indonesia
}

\author{
Sri Joeda Andajani \\ Faculty of Social Sciences and \\ Law, Universitas Negeri Surabaya, \\ Indonesia \\ Department of Geography Education \\ Faculty of Social Sciences and Law \\ Surabaya, Indonesia \\ bambangsigit@unesa.ac.id
}

\begin{abstract}
This study was inspired by the confusion of academic data at Postgraduate Program. Improving data by relying on the SIAKADU program as the mainstay of PPTI State University of Surabaya (Unesa) is just a pile of data that has no meaning. Therefore, through this evaluative research, the data collected in SIAKADU program is evaluated and processed to obtain information and have meaning. Through the technique of collecting data from SIAKADU application, the results can be obtained as follows: (1) SIAKADU academic data that can be studied includes; (a) menu of Course Lesson Plan (RPS), (b) menu of print order by lecturer, and list of Final Test/Midterm Test questions, (c) menu of lecturers questionnaire and registration per semester; (2) The programs produced in this study include; (a) planning an intensify learning devices program to the lecturers through massive collection by the head of the Study Program with UPM, (b) limitation on the number of course subjects that postgraduate lecturers must teach based on the scientific capabilities, (c) optimizing the doctoral staff potential to assist professors in teaching, so that a mature scientific development occurs from their seniors, (d) increasing an intense communication between heads of study programs and UPM in order to carry out balanced academic functions; (e) academic mentoring program by optimizing the role of academic supervisors for postgraduate and doctoral students who had run out their maximum time of courses.
\end{abstract}

Keywords: Data analysis, siakadu, work program, and academic section

\section{INTRODUCTION}

Data is a plural word from datum. The plural data will have no meaning if it is not touched by human hands and minds to be processed into data which will provide accurate information. Academic data in each department at UNESA collected through the SIAKADU program is quite a lot. However, if it is not be processed it will only be a pile of information that does not give meaning to the institution. The real example of data about the number of students in the SIAKADU program can be accessed orderly in every semester. This data only provides information about the name and number of each class. When the data is put together into a single unit that is processed, it will be very meaningful information related to the mapping of socialization programs for new student recruitment, preparation of completion programs for student graduation, preparation of accelerated study programs, student problem solving assistance programs, etc.

The interim result study of postgraduate quality assurance division found meaningless data except only information on names, classes, and the number of students as illustrated below: 


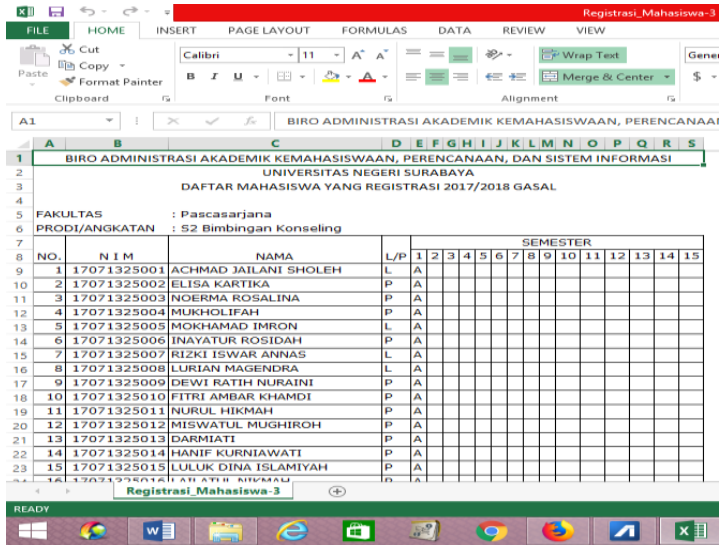

Pic: 1 List of academic guidance for postgraduate students This data is only an example and it is available on SIAKADU. This data will have meaning after it is processed, as illustrated below.

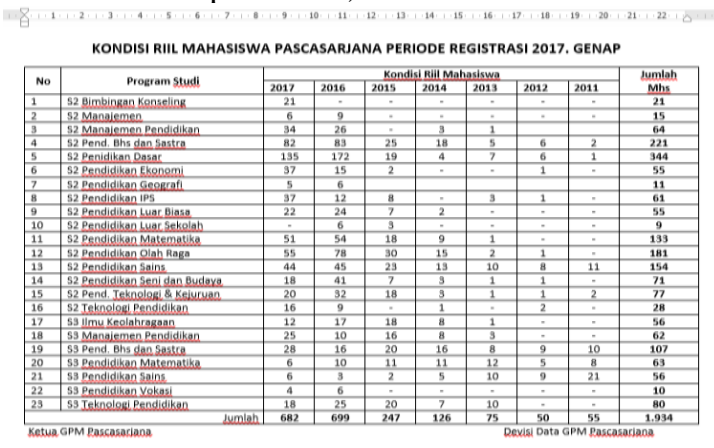

(i) 9 ? 9 (3)

Pic; 2 Data processing result of postgraduate students' condition

From the data processing results of postgraduate students' condition, class of 2013, 2012, and 2011 that still have not graduated in 2018 (180 students), it will produce some research problems that can be used as academic priority programs including: (1) mapping of graduation assistance program, (2) intensive mentoring revitalization program, (3) program of accelerated completion of the study, etc.

All of those data are only examples. If we were take a look at SIAKADU data, there is a raw data that can be processed for compiling performance program of the head of postgraduate program. Raw data that can be processed is; student data for each study program, lecturer teaching schedule data, student achievement data, student graduation data, teaching journal data etc. Therefore, the research team conducted evaluation research to examine all academic data in Siakadu and was processed as a basis for mapping the priority programs of the head of postgraduate in the future. The problem that can be formulated based on the background of the study is; (1) how can the academic data that available at SIAKADU be evaluated based on criteria needed by accreditation forms, especially management forms?, (2) how can the evaluation data be processed as a source of information and basis for determining the priority program of Postgraduate Quality Assurance Organization to develop postgraduate academic program?. The purpose of the study are (1) evaluating academic data which is available at SIAKADU with the required data on the management form, (2) processing the evaluation data as a basis for preparing priority program of Quality Assurance
Organization to develop postgraduate academic program. While the benefits obtained from this study are (1) enrich scientific knowledge about the importance of data as a source of information, (2) as an input for each study program that related to the data requirements for accreditation form, (3) provide knowledge about the importance of data that have been processed to determine the priority program of an institution including postgraduate, for instance; strengthen the performance program of postgraduate academic section in terms of equal distribution of the potential of lecturers so there is no more material buildup on certain lecturers, program to accelerate the study of graduate students, mapping of manuscript assistance program, and so on.

Data in a general context can be interpreted as something that has no meaning for the recipient and still requires a processing. Data can be in the form of circumstances, images, sounds, letters, numbers, mathematics, languages or other symbols that we can use to see the environment, objects, events or concepts. Based on Baridwan [1], that data is information about something that has often happened and in a set of facts, numbers, graphics, tables, images, symbols, letters, and words, which express a thought, objects, also conditions and situations. While Wijayanto [2], stated that data is all facts and numbers that can be used as material to compile information, while information is the result of processing data that used for a purpose. Purnomo [3] also revealed that data is a collection of information which obtained from the results of an observation where data can be in the form of numbers or symbols. In addition, Bodnar [4] said that data is a reality that describes an event and is a real entity that will later be used as the basic material for information. While Romney [4], stated that data is a set of facts and a fact is nothing but a reality or event. Romney [5] explained that data is a collection of information obtained from an observation, and it can be a number, symbol, or character. Moreover, Setiawan \& Munir [6] stated that data is a collection of events that occur in the real world in the form of numbers, letters, special symbols, or a combination of all of them. Wahyudi [7] said that data is a statement or information about the object of research. Then, stated that data is raw material in an information, or a regular group of symbols that representing quantities, facts, actions, objects, and so on. Arikunto[8] explained that data is information or evidence about a fact that is still raw, still independent, unorganized, and unprocessed.

Information is the result of processing from a model, formation, organization, or a change in form of data that has certain values, and can be used to increase knowledge for those who receive it. In this case, data can be considered as an object, while information is a subject that is beneficial for the recipient. Information can also be called as a result of processing the data.

Data can be working hours for employees in the company. This data needs to be processed and converted into an information. If the working hours of each employee are multiplied by the hourly value, so a certain value will be generated If the income of each employee is added up, then it will show a recapitulation of the salary that must be paid by the company. Payroll is an information for the company owners. Information is the result of processes from existing 
data, or can be interpreted as data that has meaning. Information will open the unknown things.

\section{RESEARCH METHOD}

The research design used in this study is evaluative research by collecting the documents from SIAKADU program developed by PPTI as the data sources. Academic data in SIAKADU program will be evaluated based on the criteria of data needed by accreditation forms for managers. The evaluation result will be analyzed quantitatively and qualitatively as the basis for determining academic priority programs in the institution.

The description of the design is as follows.

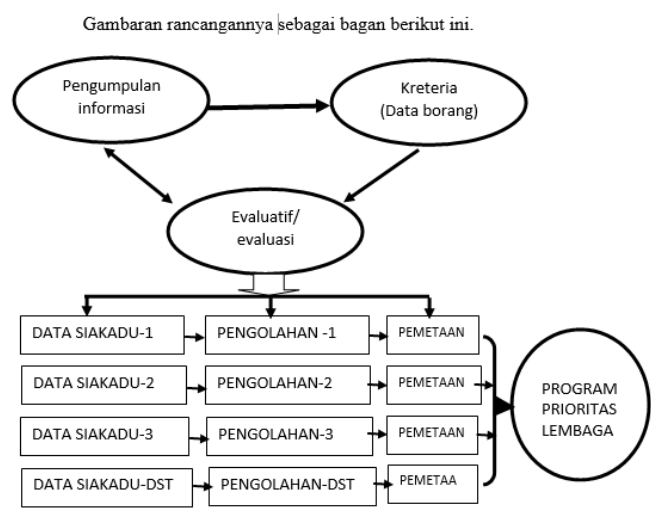

Bagan: 1 Rancangan Penelitian Evaluasi (Adaptasi Arikunto, 2010)

The object of this research are the academic data stored in SIAKADU of Unesa postgraduate program. Those are student condition data, student GPA data, student guidance data, teaching journal data, student graduation data, teaching schedule data, lecturer teaching hours distribution data, etc [9].

Observation was conducted to collect the data by observing the data stored in SIAKADU and did documentation by accessing and downloading the data stored in SIAKADU, after that it will be inventoried based on the type of data, then evaluated.

Furthermore, the data collected will be analyzed using flow analysis models, the data obtained was directly flows to be arranged narratively both quantitatively and qualitatively [10], so the results can provide a clear information as a basis for mapping institutional priority programs.

\section{RESULTS AND DISCUSSION}

\section{A. RESULTS}

An overview of the data contained in SIAKADU is by logging in as the Head of the Postgraduate Quality Assurance. The entire menu in SIAKADU of postgraduate program is identified to be analyzed so it can be a real work program for GTM. There are 3 (three) main menus in SIAKADU: (1) Courses and Curriculum, including sub menu for RPS; (2) Lectures, including sub-menus; (a) class and schedule (print order by day; print order by class, print order by room, print order by lecturer, print order by lecturer (global), (b) list of Final Test/Midterm Test questions, (c) print class data (attendance, summary of attendance, print
DPNA, BA Final Test, Exam attendance, Print journal, BM attendance), (d) Graduation Process and Graduation Ceremony; (3) Report, including sub-menus; (a) summary (summary of lecturer's questionnaire, summary of journals, registration per semester, and registration per semester All), (b) questionnaire (students and graduation, number of lecturers/class, study program's lecturer data, permanent lecturers activity, research activity, service activity, distribution of lecturer's homebase), (c) graduate profile (graduate statistics, and summary of graduates' GPA), (d) print main book. Each menu was identified and selected to be analyzed according to the needs of the accreditation forms. The results of data analysis in SIAKADU can be described as follows.

\section{Course Lesson Plan (RPP) as research material}

RPS data in Postgraduate program was available on SIAKADU Unesa. However, after open the SIAKADU, all of 23 study programs of postgraduate and doctoral program still not fulfill their obligation to submit journals through the postgraduate website. During brainstorming between head of study programs, the obstacle faced by them is not all classes have a good internet network, so they cannot directly access the internet during lectures. It shows in table 1.

\begin{tabular}{|c|c|c|c|c|c|}
\hline \multirow[b]{2}{*}{ No } & \multirow[b]{2}{*}{ STUDY PROGRAM } & \multirow[b]{2}{*}{$\underset{\mathrm{E}}{\text { COURS }}$} & \multicolumn{3}{|c|}{ RPS CONDITION } \\
\hline & & & $\begin{array}{l}\text { VALIDA- } \\
\text { TED }\end{array}$ & $\begin{array}{l}\text { UNVALID } \\
\text { ATED }\end{array}$ & $\begin{array}{l}\text { NOT } \\
\text { AVAII } \\
\text {-ABLE }\end{array}$ \\
\hline$\frac{1}{2}$ & $\begin{array}{l}\text { S2 BK } \\
\text { S2 }\end{array}$ & $\begin{array}{l}12 \\
20\end{array}$ & 2 & - & 10 \\
\hline 3 & S2 Manajemen Pendidikan & 33 & 10 & $i_{2}$ & 21 \\
\hline 4 & S2 Bahasa dan Sastra & 119 & 25 & 2 & 92 \\
\hline 5 & S2 Pendidikan Dasar & 51 & 15 & 1 & 35 \\
\hline 6 & S2 Pendidikan Ekonomi & 50 & 8 & 3 & 39 \\
\hline 7 & S2 Pendidikan Geografi & 14 & 11 & 3 & - \\
\hline 8 & S2 Pendidikan IPS & 27 & 8 & 2 & 17 \\
\hline 9 & S2 Pendidikan Luar Biasa & 19 & 6 & 6 & 7 \\
\hline 10 & S2 Pendidikan Luar Sekolah & 17 & - & 8 & 9 \\
\hline 11 & S2 Pendidikan Matematika & 21 & 2 & 2 & 17 \\
\hline 12 & S2 Pendidikan Olah Raga & 29 & 5 & 3 & 21 \\
\hline 13 & S2 Pendidikan Sains & 48 & 13 & 1 & 34 \\
\hline 14 & S2 Seni Budaya & 30 & 13 & 1 & 16 \\
\hline 15 & S2 Pedidikan Telnik Kejuruan & 36 & 7 & 2 & 27 \\
\hline 16 & S2 Teknologi Pendidikan & 27 & 1 & 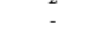 & - \\
\hline 17 & S3 Ilmu Keolahragaan & 23 & 3 & 1 & 19 \\
\hline 18 & S3 Manajemen Pendidikan & 21 & 8 & - & 13 \\
\hline 19 & S3 Pendidikan Bhs dan Sastra & 36 & 2 & - & 34 \\
\hline 20 & S3 Pendidikan Matematika & 19 & - & - & 19 \\
\hline 21 & S3 Pendidikan Sains & 18 & $i$ & - & 17 \\
\hline 22 & S3 Pendidikan Vokasi & 15 & 2 & 7 & 6 \\
\hline \multirow[t]{3}{*}{23} & S3 Teknologi Pendidikan & 13 & 1 & - & 12 \\
\hline & 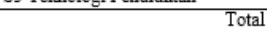 & 698 & 164 & 44 & 465 \\
\hline & Percentage & & $23.49 \%$ & $6.30 \%$ & $66.62 \%$ \\
\hline
\end{tabular}

This data can be analyzed that RPS should have 698 courses, $23.49 \%$ (164 MK) validated, $6.30 \%$ (44 MK) not validated, dan $66.62 \%$ (465 MK) still not available in RPS. This result can be used to arrange the work program as follows; (a) Planning a program to intensify learning devices for lecturers through massive collection by the head of the study program with UPM, (b) The sanctions for lecturers who do not upload RPS on the PPTI application system should be practiced, (c) Discipline the lecturer's performance through online systems from learning devices to assessment, (d) The implementation of curriculum restructuring must be completed up to the RPS.

\section{Class and Schedule as research material}

Class and Schedule data from menu print order by lecturer and combines with the result of identification data from questionnaire, will get information about teaching distribution and the real number of postgraduate lecturers. 
The raw data from SIAKADU in menu print order by lecturer was shown as follows.

This real condition can be analyzed to make work program for academic section, as follows: (1) The distribution of teaching hours for postgraduate lecturer based on their capabilities and qualifications, (2) Limitations on the number of subjects that postgraduate lecturers must teach based on scientific capabilities, (3) The implementation of assistance program or apprenticeship for junior lecturers to senior lecturers, also to minimize lecture emptiness, because team teaching has been implemented, (4) Socialization of remuneration regulations to lecturers to minimize the imbalance teaching hours at postgraduate program.

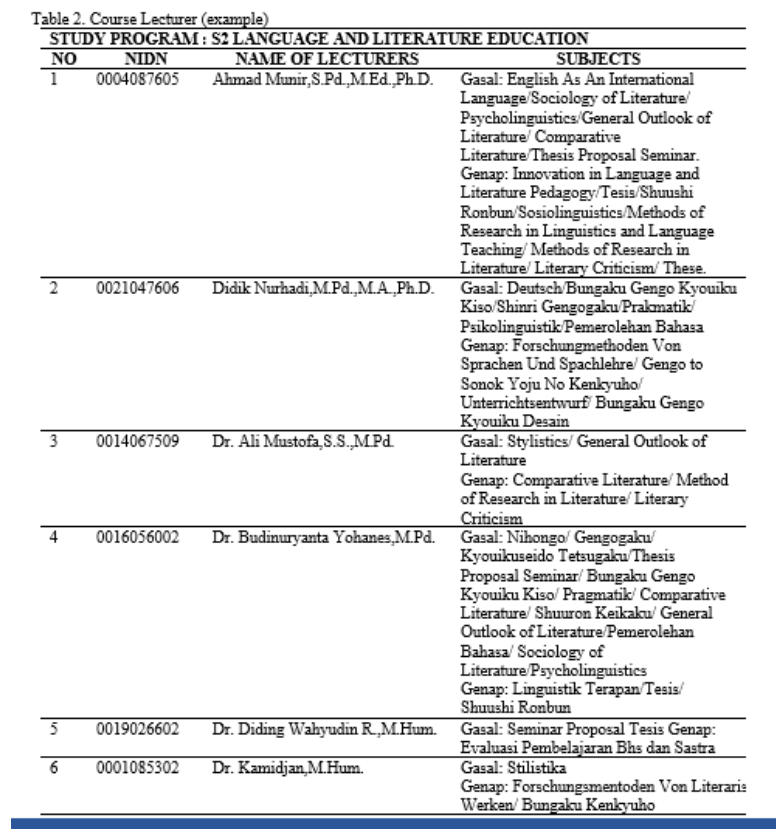

Based on the result of questionnaire, it can be analyzed with academic program as follows; (1) rearrangement of teaching hours based on scientific fields, not based on functional positions or structural positions, (2) optimizing the doctoral staff potential to assist professors in teaching, so that a mature scientific development occurs from their seniors, (3) limitation on the number of subjects that lecturers can teach outside the home base, so it is not look like a scientific expansion.

\section{List of Final Test/Midterm Test questions as research material}

The source of this data is from SIKADU in menu lectures. The data showed lecturers' activities on doing evaluation both for Midterm Test and Final Test. Data filled in SIAKADU of postgraduate program shows the representative level of seriousness of postgraduate lecturers in teaching. The level of seriousness and concern on their duty are shown in Table 3.

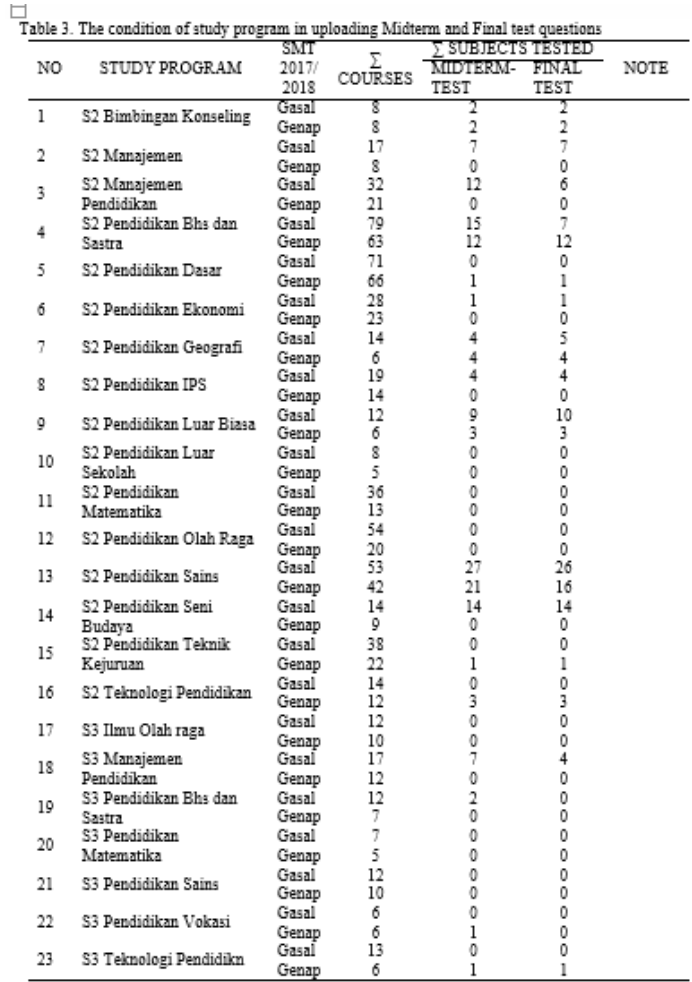

Based on Table 3, the data can be analyzed as an academic program as follows; (1) reaffirmation of the quality procedures and academic guidelines about the form of the question and the decision to upload or not the question on SIAKADU depends on the head of postgraduate program, (2) increasing an intense communication between heads of study programs and UPM in order to carry out balanced academic functions, (3) review the monitoring and evaluation instruments about Midterm Test and Final Test, (4) accelerated program for postgraduate lecturers to raise their awareness towards IT developed by institutions through SIAKADU.

\section{Registration Recapitulation per Semester as research material}

The source of this data is from SIAKADU in menu Registration per Semester. The data showed the real condition of students per semester until the year registration 2017.2. Data has been inventoried in tabulation and needs to be analyzed to develop academic program. The summary of registration per semester can be seen in Table 4 as follows.

Data in table 4 showed that there is a lot of postgraduate and doctoral students have finished their courses. Based on the analysis result of real condition of students in a year class 2014, 2013, and 2012, there are 179 students still registered as a student at year registration 2018.1 . 


\begin{tabular}{|c|c|c|c|c|c|c|c|c|c|}
\hline \multirow[b]{2}{*}{ No } & \multirow[b]{2}{*}{ Study Program } & \multicolumn{7}{|c|}{$\begin{array}{l}\text { Students' Real Conditions } \\
\text {. }\end{array}$} & \multirow{2}{*}{$\begin{array}{l}\text { Num of } \\
\text { Studen } \\
\text { ts }\end{array}$} \\
\hline & & 2018 & 2017 & 2016 & 2015 & 2014 & 2013 & 2012 & \\
\hline 1 & S2 Bimbingan Konseling & 13 & 21 & i & - & - & - & & \\
\hline 2 & \$2 Manajemen & 18 & 6 & 9 & - & & & & 33 \\
\hline 3 & S2 Manajemen Pendidikan & 21 & 34 & 18 & $\therefore$ & 2 & 1 & 2 & 78 \\
\hline 4 & S2 Pend Bhs dan Sastra & 44 & 79 & 67 & 21 & 13 & 5 & 2 & 231 \\
\hline 5 & S2 Penidikan Dasar & 90 & 131 & 98 & 10 & 3 & 3 & 3 & 338 \\
\hline 6 & S2 Pendidikan Ekonomi & 10 & 36 & 13 & 1 & - & - & - & 60 \\
\hline & S2 Pendidikan Geogra & 4 & 5 & 6 & & & & & 15 \\
\hline 8 & S2 Pendidikan IPS & 17 & 37 & 9 & 6 & - & - & - & 69 \\
\hline 9 & \$2 Pendidikan Luar & 16 & 22 & 6 & 7 & 2 & - & - & 53 \\
\hline 10 & S2 Pendidikan Luar & 5 & 1 & 5 & 5 & & - & & 16 \\
\hline 11 & \$2 Pendidikan Ma & 28 & 50 & 49 & 14 & 7 & - & 1 & 149 \\
\hline 12 & \$2 Pendidikan 0 & 18 & 53 & 23 & 11 & 4 & $\therefore$ & 1 & 110 \\
\hline 13 & S2 Pendidikan & 57 & 42 & 33 & 21 & 10 & 8 & 6 & 137 \\
\hline 14 & \$2 Pen & 20 & 17 & 31 & 6 & 1 & - & - & 75 \\
\hline & S2 Pend T & 17 & 19 & 24 & 16 & 5 & 1 & - & 82 \\
\hline 16 & \$2 Tek & 13 & 16 & 3 & & 1 & & - & 33 \\
\hline & $\$ 33 \mathrm{Ilm}$ & 1 & 12 & 17 & 18 & 4 & 1 & - & 53 \\
\hline 18 & & 16 & 25 & 10 & 16 & 6 & 4 & - & 37 \\
\hline 19 & S3 P & 12 & 28 & 16 & 19 & 1 & 8 & 8 & 92 \\
\hline 20 & matika & 11 & 5 & 10 & 10 & 11 & 12 & 5 & 64 \\
\hline 21 & S3 Pendidikan Sair & 4 & 6 & 3 & 2 & 5 & 10 & 8 & 38 \\
\hline 22 & S3 Pendidikan Vokasi & 5 & 4 & 4 & & & & & 13 \\
\hline 23 & S3 Teknologi Pendidikan & 7 & 17 & 5 & 18 & 7 & 2 & 6 & 62 \\
\hline & & & 666 & 459 & 201 & 82 & 55 & 42 & 1.952 \\
\hline
\end{tabular}

(Sources: Siakadu Registrasi 2018.1)

This can be used as reference to arrange work program for academic section, as follows; (1) study rescue program to students who have exceeded the maximum time of postgraduate and doctoral study, (2) arrange a program to find out students' problem on exceeded the maximum time of postgraduate and doctoral study, (3) Academic mentoring program by optimizing the role of academic supervisors for postgraduate and doctoral students who had run out their maximum time of courses. The result of academic section's work program can be shown in Table 5 .

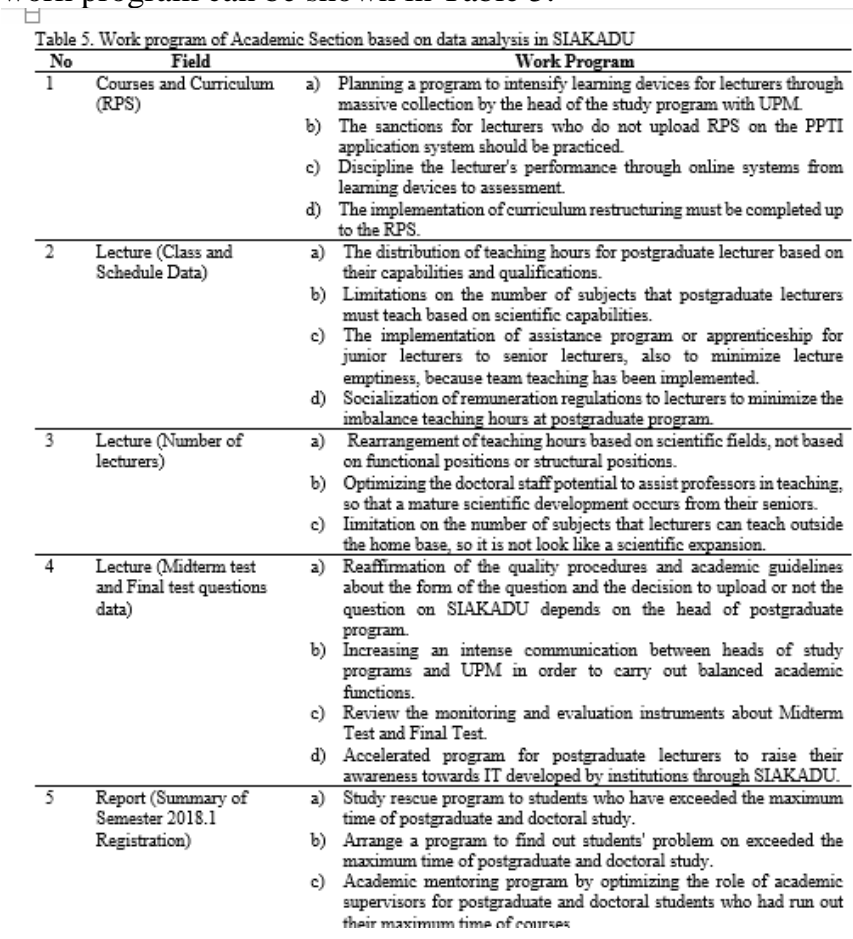

\section{B. DISCUSSION}

The results of this study indicated that data that has been analyzed intensively will create a program for institution. Program that has been produced in this research based on the priority are (1) Planning an intensify learning devices program to the lecturers through massive collection by the head of the Study Program with UPM, (2) Limitation on the number of course subjects that postgraduate lecturers must teach based on the scientific capabilities, (3) Optimizing the doctoral staff potential to assist professors in teaching, so that a mature scientific development occurs from their seniors, (4) Increasing an intense communication between heads of study programs and UPM in order to carry out balanced academic functions; (5) Academic mentoring program by optimizing the role of academic supervisors for postgraduate and doctoral students who had run out their maximum time of courses.

The function of this data analysis is in line with Deputy Mayor of Magelang, Windarti [11] said that "The availability of data and well understanding of those data will be the key to achieve development accuracy," (September, $25^{\text {th }}$ 2017). Furthermore, all public service provider must have a good understanding about the importance of data to increase the working performance and continuity of public services in Magelang city. Furthermore, data can increase the contribution of public service provider in providing an appropriate, accurate and sustainable primary data and increase awareness of making data as the main instrument in planning, control and basic evaluation of work results. DataGO, said Windarti, is a website-based data management information system as an effort of the City Government of Magelang to improve the quality of data management through the establishment of a structured database, which is able to present high-quality, up-to-date and representative data and statistics.

Information and Statistics Office (Diskominsta) of Magelang City, management and collection of integrated data is expected to be the only data source that can be accessed by all parties. This is intended to avoid inconsistencies and duplication of data which will be used. According to UU No 25 Tahun 2004 about National Development Planning System, stated that development planning is based on accurate and accountable data and information. Catur also explained that each region must strive to have matured sectoral data management with the substance of information that meet all development planning documents. "This is also related to information disclosure to the public. The data presented must be precise and accurate," said Catur when explaining about socialization and exposure of strategic data in commemoration of National Statistics Day in Adipura Kencana hall.

Connolly \& Begg [12] gave illustrates several advantages of analyzing data for a research. Several advantages of analyzing data are: (a) get clearer measurement results, (b) reliable identification process, (c) possible to identify important things, (d) can be seen visually so it helps in making decisions quickly and precisely, (e) in business activities, it help the process of identifying problems that require action or decision, (f) have a better awareness of customers potential.

\section{CONCLUSION}

The result of this study can be concluded as follows; (1) Academic data which is available in postgraduate SIAKADU, can be evaluated based on the criteria that accreditation form needed especially management form, include: (a) Courses and Curriculum menu with Course Lesson Plan (RPS) as research material, (b) Lecture menu with print order by lecturer and list of Final Test/Midterm Test questions as research material, (c) Report menu with lecturer questionnaire and registration per semester as research; (2) The programs produced in this study include: (a) planning an intensify learning devices program to the 
lecturers through massive collection by the head of the Study Program with UPM, (b) limitation on the number of course subjects that postgraduate lecturers must teach based on the scientific capabilities, (c) optimizing the doctoral staff potential to assist professors in teaching, so that a mature scientific development occurs from their seniors, (d) increasing an intense communication between heads of study programs and UPM in order to carry out balanced academic functions; (e academic mentoring program by optimizing the role of academic supervisors for postgraduate and doctoral students who had run out their maximum time of courses.

Based on the result of this study, it can be suggested as follows; (1) The head of postgraduate program need to act decisively by giving sanctions to the lecturers who intentionally did not do their duty in fulfilling lecture devices, (2) The head of the study program need to improve the communication with UPM so those relationship was established in strengthening academic assignments, especially lecturers' duty on fulfilling the demands of applications in SIAKADU, (3) The program of Postgraduate Quality Assurance Organization must be more operational that the head of study program can implement through the application developed by PPTI Unesa, (4) Intense communication is still needed between units at the postgraduate program to optimize the performance achievement of each unit.

\section{REFERENCES}

[1] Z. Baridwan, Sistem Informasi Akuntansi, Ketujuh. Yogjakarta: BPFE Yogjakarta, 2000.

[2] N. Wijayanto, Sistem Informasi Akuntansi, Ke tiga. Jakarta: Erlangga Press, 2001.

[3] E. Purnomo, Aspek-Aspek EDP Audit Pengendalian Internet Data Komputerisasi, Pertama. Yogjakarta: Andi Offset, 2004.

[4] G. H. dan W. S. H. Bodnar, Acconting Informations Systems, Ke sembila. Pearson Education International, 2004.

[5] M. B. dan P. J. S. Romney, Accounting Information System, Buku 1 edi. Jakarta: salimba empat, 2005.

[6] W. dan M. Setiawan, Pengantar Teknologi Informasi, Pertama. Pengantar Teknologi Informasi: Sistem informasi Bandung, 2006.

[7] B. Wahyudi, Konsep Data dan Informasi, Pertama. Jakarta: salimba empat, 2010.

[8] S. Arikunto, Prosedur Penelitian, suatu Pendekatan Praktik. 2010.

[9] M. Singarimbun, Metode Penelitian Survai, LP3ES ed. Jakarta: LP3ES, 1989.

[10] J. R. dan S. Tarigan, Metode Pengumpulan Data, Ke satu. Yogjakarta: BPFE, 1999.

[11] Windarti, "Pengolahan Data di Magelang," Magelang, p. 5, Sep-2017.

[12] C. T. dan B. C., atabase Systems: A Practical Approach in Design, Implementation, and Management., Fourth Edi. USA: Addison Wesley. Longman Inc., 2005. 